\title{
Influence of calcium and phosphorus feeding on markers of bone metabolism in transition cows
}

\author{
V. R. Moreira, ${ }^{* 1}$ L. K. Zeringue, ${ }^{*}$ C. C. Williams, $†$ C. Leonardi, $\ddagger$ and M. E. McCormick ${ }^{*}$ \\ *Louisiana State University AgCenter Southeast Research Station, Franklinton 70438 \\ †Louisiana State University AgCenter School of Animal Sciences, and \\ łLouisiana State University Department of Experimental Statistics, Baton Rouge 70803
}

\section{ABSTRACT}

A study was carried out to verify the effect of Ca and $\mathrm{P}$ levels on production, digestibility, and serum bone metabolism biomarkers in dairy cows. Fifty-two nonlactating multiparous cows $(\geq 3$ lactations) were confined in a free-stall barn approximately $20 \mathrm{~d}$ before calving. A standard close-up diet was fed to cows once daily until d 2 postpartum. Cows were randomly assigned to 1 of 4 dietary treatments arranged in a $2 \times$ 2 factorial approach averaging $0.64 \% \mathrm{Ca}$ for high $\mathrm{Ca}$ (HCa), $0.46 \%$ Ca for low Ca (LCa), $0.47 \%$ P for high $\mathrm{P}$ (HP), and $0.38 \% \mathrm{P}$ for low $\mathrm{P}$ (LP) on a dry matter basis. Experimental diets were fed twice daily from $3 \mathrm{~d}$ in milk (DIM) until 31 DIM. Intake and milk yield were recorded daily. Milk samples were collected on d 28, 29 , and 30 postpartum for components analyses. Blood samples were drawn $10 \mathrm{~d}$ before expected calving, at calving, and at 15 and 30 DIM for serum analyses of osteocalcin, a biomarker of bone accretion, and pyridinoline, a biomarker of bone resorption. Total fecal collection was conducted when cows in a block averaged 20 DIM. Intake and production traits were not significantly affected by any of the dietary treatments. Cows averaged nearly $21 \mathrm{~kg} / \mathrm{d}$ dry matter intake and $44 \mathrm{~kg} / \mathrm{d}$ milk yield from 6 to 31 DIM. There were no significant differences across treatments in body weight or body condition score loss. Phosphorus intake, $\mathrm{P}$ fecal output, $\mathrm{P}$ digestibility, and $\mathrm{P}$ apparent absorption were affected by dietary $\mathrm{P}$ content. Calcium intake was higher with $\mathrm{HCa}$, but $\mathrm{Ca}$ fecal output, digestibility, and apparent absorption showed an interaction between dietary $\mathrm{Ca}$ and dietary P. Calcium fecal output was $100.6 \mathrm{~g} / \mathrm{d}$ for cows fed HCaHP, intermediate for cows on the HCaLP diet $(89 \mathrm{~g} / \mathrm{d})$, and similar among cows fed the $2 \mathrm{LCa}$ diets $(70 \mathrm{~g} / \mathrm{d}$ with LCaHP and 75 with LCaLP). There was no significant effect of $\mathrm{Ca}$ or $\mathrm{P}$ on osteocalcin measurements. Pyridinoline concentrations

Received April 10, 2009

Accepted June 13, 2009.

${ }^{1}$ Corresponding author: vmoreira@agcenter.lsu.edu were affected by dietary Ca levels and tended to have a significant dietary $\mathrm{Ca} \times$ dietary $\mathrm{P}$ interaction. Phosphorus apparent digestibility occurred independently of dietary Ca levels. Results of this study suggest that more bone was mobilized in cows fed LCa diets, but excess dietary $\mathrm{P}$ caused greater and prolonged bone mobilization regardless of dietary Ca content.

Key words: cow, bone, calcium, phosphorus

\section{INTRODUCTION}

Daily dietary mineral requirements for lactating dairy cows have been more precisely defined since the development of the factorial approach to estimating nutrient requirements in the mid-20th century. A factorial approach considers the sum of maintenance, lactation, pregnancy, and growth requirements corrected for absorption coefficients (NRC, 2001). More recently, uncertainty associated with measurements of maintenance requirements (Spiekers et al., 1993) and absorption coefficients (Martz et al., 1990; Knowlton and Herbein, 2002), and fear of poor productive (Kincaid et al., 1981; Valk and Šebek, 1999), reproductive (Lopez et al., 2004a,b), and health (Wu et al., 2000, 2001) performances justified several feeding trials evaluating dietary $\mathrm{P}$ recommendations for high-producing dairy cows. Long-term studies indicate that cows fed dietary $\mathrm{P}$ at a flat rate of $0.32 \%$ throughout the lactation can support 9,000 kg of milk production or more (Kincaid et al., 1981; Valk and Šebek, 1999; Knowlton and Herbein, 2002). In a few other trials, nonetheless, cows fed dietary $\mathrm{P}$ concentrations as low as 0.28 and $0.31 \%$ were able to maintain high productive performance (Valk and Šebek, 1999; Wu et al., 2001). It should be noted, however, that lactation studies including marginal concentrations of dietary $\mathrm{P}$ invariably assume that cows can cope with deficiency during early stages of lactation.

Hormonal control of $\mathrm{P}$ homeostasis is not completely understood but is thought to be closely related and mostly secondary to Ca homeostasis (Horst, 1986; Breves and Schröder, 1991). Calcium metabolism in dairy cows is tightly regulated by parathyroid hormone 
(PTH) and vitamin D metabolites stimulating bone resorption of $\mathrm{Ca}$ and $\mathrm{P}$ in response to hypocalcemia. Intestinal absorption of $\mathrm{Ca}$ and $\mathrm{P}$ occurs primarily by passive diffusion when cows are fed diets containing sufficient amounts of those minerals. Hypophosphatemia and hypocalcemia along with PTH can independently induce 25-hydroxycholecalciferol renal hydroxylation to 1,25-dihydroxycholecalciferol $\left[\mathbf{1}, \mathbf{2 5}-(\mathbf{O H})_{2} \mathbf{D}_{3}\right]$. Vitamin $\mathrm{D}$ metabolites promote active intestinal transport of $\mathrm{Ca}$ and $\mathrm{P}$ across the epithelial cells (Breves and Schröder, 1991; Horst et al., 1994; Goff, 2006).

It has been suggested that 0.8 to $1.3 \mathrm{~kg}$ of $\mathrm{Ca}$ can be mobilized from the bones of adult cows to cope with absorption deficiencies (dietary or physiological) and with high milk production in early lactation (Liesegang et al., 2000; NRC, 2001). Most cows are likely in negative balance during the first $10 \mathrm{~d}$ of lactation because of slow adaptation of $\mathrm{Ca}$ absorption mechanisms in response to the sudden increase in Ca demand for milk production after calving. Positive balance should be reestablished by 45 to 60 DIM (NRC, 2001). Most body P is stored as hydroxyapatite and calcium phosphate in the bones at a 1.67:1 ratio of Ca: P (Ternouth, 1990; Goff, 2000). Assuming $\mathrm{P}$ is mobilized along with $\mathrm{Ca}$ from bones at a similar rate, it can be estimated that 0.5 to $0.8 \mathrm{~kg}$ of $\mathrm{P}$ could be made available from bone resorption in the first few weeks of lactation, which is equivalent to saying that $\mathrm{P}$ resorption can supply $\mathrm{P}$ secreted into 26 to $42 \mathrm{~kg}$ of milk/d during the first $21 \mathrm{~d}$ of lactation. The requirement models described in NRC (2001) did not credit $\mathrm{Ca}$ or $\mathrm{P}$ mobilization from bones.

Few studies evaluated the effect of $\mathrm{P}$ on bone metabolism in ruminants. Braithwaite $(1983 \mathrm{a}, \mathrm{b})$ fed ewes 2 diets containing $\mathrm{Ca}$ and $\mathrm{P}$ either above or below dietary requirements and injected $\mathrm{Ca}$ and $\mathrm{P}$ trace isotopes intravenously for a kinetics study. Although bone resorption was not measured, the author suggested that $\mathrm{Ca}$ bone resorption occurred at a constant rate because of limited intestinal absorption during late pregnancy and early lactation. Ekelund et al. (2006) fed a group of cows a diet containing $0.64 \% \mathrm{Ca}$ and either $0.32 \% \mathrm{P}$ for the first 4 mo of lactation followed by $0.43 \%$ dietary $\mathrm{P}$ for the remainder of the lactation period or $0.43 \%$ dietary $\mathrm{P}$ throughout the lactation. Changes in bone metabolism indicators in blood [osteocalcin (OC) and cross-linked carboxyterminal telopeptides of type-I collagen $(\mathbf{C T x})$ ] showed a similar pattern of mobilization during early lactation, but higher osteocalcin indicated more bone accretion with $0.43 \%$ dietary $\mathrm{P}$ between 14 and $24 \mathrm{wk}$ of lactation. Kichura et al. (1982) fed 9.5 or $86 \mathrm{~g}$ of $\mathrm{Ca}$ and 10 or $82 \mathrm{~g}$ of $\mathrm{P}$ to cows for $20 \mathrm{~d}$ before calving. The authors concluded that gastrointestinal absorption of $\mathrm{Ca}$ and $\mathrm{P}$ was more efficient in cows fed 10 $\mathrm{g}$ of $\mathrm{P}$, possibly as a result of greater numbers or higher efficiency rate of intestinal receptors for $1,25-(\mathrm{OH})_{2} \mathrm{D}_{3}$. Results from the studies discussed above suggest that $\mathrm{P}$ homeostasis is secondary to Ca metabolism control. It is frequently noted in $\mathrm{P}$ feeding trials that $\mathrm{P}$ metabolism in bones is subject to Ca supply in early lactation. However, studies concurrently investigating the effect of dietary $\mathrm{Ca}$ and $\mathrm{P}$ fed to early-lactation cows on animal performance and on markers of bone metabolism could not be found in the literature.

It was hypothesized that the effect of dietary P levels on bone metabolism in early-lactation dairy cows depends on dietary Ca content, warranting attention to both minerals when preparing diets for cows in the transition period. The objective of this study was to evaluate the influence of dietary $\mathrm{Ca}$ and $\mathrm{P}$ levels on performance and bone metabolism markers of cows during the first month of lactation.

\section{MATERIALS AND METHODS}

This experiment was conducted at the Louisiana State University Agricultural Center Southeast Research Station, located in Franklinton, Louisiana, after the protocol was approved by the Louisiana State University Agricultural Center Institutional Animal Care and Use Committee.

\section{Animals and Management}

Fifty-two multiparous cows (3 lactations or more) were utilized in a randomized block design. Cows were grouped by expected calving date in 13 blocks of 4 cows each. Six cows were removed from all data sets before statistical analyses because of issues unrelated to treatments. Three cows were removed before treatments were applied because of calving too early, mastitis/ pneumonia, and postpartum paralysis. Another cow was removed within a week after calving because of coliform mastitis. Two cows completed the study but were later removed for poor performance (deemed outlier) and a displaced abomasum.

The study was carried out between October and May of 2004-2005 and 2005-2006. Animals were housed in a free-stall barn fitted with electronic gates (American Calan Inc., Northwood, NH) for individual feeding. Each block of cows was brought to the barn when cows were at least $20 \mathrm{~d}$ before expected calving date and remained in the study until the last cow in each block reached 31 DIM. For calving comfort, dry cows had free access to a grassed area, which was mowed as needed to limit consumption of fresh herbage. Cows were randomly assigned to 1 of 4 treatments before calving. Treatment feeding began $3 \mathrm{~d}$ after calving. Blocks of cows remained in the barn on average for 65 
Table 1. Mean chemical composition ( \pm SD, \% of DM) of the forages

\begin{tabular}{lccc}
\hline Item & Alfalfa hay & Bermuda hay & Corn silage \\
\hline CP & $19.9 \pm 1.23$ & $14.5 \pm 0.83$ & $8.70 \pm 1.05$ \\
NDF & $43.7 \pm 3.25$ & $70.7 \pm 1.75$ & $46.3 \pm 4.08$ \\
ADF & $34.2 \pm 3.19$ & $35.1 \pm 1.01$ & $27.1 \pm 2.98$ \\
Calcium & $1.11 \pm 0.22$ & $0.38 \pm 0.05$ & $0.15 \pm 0.04$ \\
Phosphorus & $0.25 \pm 0.03$ & $0.19 \pm 0.01$ & $0.26 \pm 0.02$ \\
\hline
\end{tabular}

$\pm 5 \mathrm{~d}$, from when dry pregnant cows were brought in the barn until the last cow completed 31 DIM. Animals produced $12,130 \pm 2,090 \mathrm{~kg}$ of milk over the $305 \mathrm{~d}$ of their previous lactation. Dry cows were fed once daily, whereas lactating cows were fed $(0800$ and $1400 \mathrm{~h})$ and milked (0600 and 1700h) twice daily.

\section{Diets}

Diets were fed as TMR (Tables 1 and 2). Nutrient contents of feeds changed in the course of the study. Each block of cows was offered feeds from a single batch or harvest from the beginning to the end of their experimental period to limit changes in nutrient composition. Diets were reformulated using the same feedstuffs for each block of cows entering the study to maintain similar dietary $\mathrm{Ca}$ and $\mathrm{P}$ concentrations across the entire experiment. Treatment diets were mixed twice daily using a Data Ranger (American Calan Inc.) and offered in approximately equal portions. All cows were fed a standard close-up diet from arrival to the barn until the second day after calving. Treatment diets were offered from the third day after calving until cows left the experiment. A basal diet was formulated for mineral content below NRC (2001) recommendations. Four premixes were prepared with ground corn, calcium carbonate, and monosodium phosphate as supplements to the basal diet to obtain treatments arranged as a $2 \times$ 2 factorial giving high $\mathrm{Ca}$-high $\mathrm{P}(\mathbf{H C a H P})$, high $\mathrm{Ca}^{-}$ low P (HCaLP), low Ca-high P (LCaHP), and low Ca-low P (LCaLP), where high and low indicate nutrient contents above and below predicted requirements, respectively. Average nutrient contents calculated using actual ingredient analyses were (on a DM basis) $0.64 \%$ $\mathrm{Ca}$ in $\mathrm{HCa}$ and $0.46 \% \mathrm{Ca}$ in LCa diets, and $0.47 \% \mathrm{P}$ in $\mathrm{HP}$ and $0.38 \% \mathrm{P}$ in LP diets (Table 2).

\section{Sampling, Laboratory Analyses, and Calculations}

Daily DMI was determined from the beginning of the pretrial period until the end of the experimental period for each block of cows. Samples of TMR, feed refusals, and corn silage were collected daily, stored frozen, and subsampled weekly. Concentrates and hays were sampled weekly. Feed samples were dried at $60^{\circ} \mathrm{C}$ for $48 \mathrm{~h}$ every week. Dried samples were ground through a 2-mm screen in a Wiley mill (Arthur H. Thomas, Philadelphia, PA), and then passed through a 1-mm screen in a Cyclotec 1093 Sample Mill (Foss Tecator, Höganäs, Sweden). Ground samples were composited by month. Feed and fecal samples were analyzed for Kjeldahl N and $\mathrm{P}$ in an automated colorimetric assay adapted for flow-injection analyzer (QuickChem 8000 FIA, Lachat Instruments, Milwaukee, WI). Fibers were analyzed according to the sequential NDF/ADF analysis utilizing heat-stable amylase and sodium sulfite (Van Soest et al., 1991) modified for the Ankom ${ }^{200}$ Fiber Analyzer (Ankom Technology, Fairport, NY). Calcium, Mg, and $\mathrm{K}$ in feed samples and $\mathrm{Ca}$ in fecal samples were determined by flame atomic absorption spectrophotometry (Perkin-Elmer Analyst 300, Norwalk, CT) after dryashing at $500^{\circ} \mathrm{C}$ overnight in porcelain crucibles. Ashed samples were dissolved over heat in $5 \mathrm{~mL}$ of $20 \% \mathrm{HCl}$, transferred to $100-\mathrm{mL}$ volumetric flasks, and diluted to $100 \mathrm{~mL}$ with deionized water.

Milk production was measured in AfiFlo milk meters (SAE Afikim, Kibbutz Afikim, Israel) and recorded daily from each milking for statistical analyses by Afimilk software (Afifarm version 3.01A, SAE Afikim). Milk was sampled from 6 consecutive milkings when cows in a block averaged 28 DIM. Milk samples were analyzed by the Louisiana DHIA Laboratory (Baton Rouge) for fat and true protein by near-infrared spectroscopy (Bentley 2000, Bentley Instruments, Chaska, $\mathrm{MN}$ ), and for somatic cells in a flow cytometer (Bentley Somacount 300). Milk components were weighted based on a.m. and p.m. milk production on sampling dates.

Blood samples were drawn at $0700 \mathrm{~h}$ from coccygeal vessel into vacuum tubes (BD Vacutainer Serum, Becton Dickinson, Franklin Lakes, NJ) on d 10 before expected calving and d 1 (calving date), 15, and 30 postpartum. Whole blood samples were allowed to clot for at least $20 \mathrm{~min}$, and then centrifuged at 2,200 $\times \mathrm{g}$ for $30 \mathrm{~min}$ at $4^{\circ} \mathrm{C}$ (Marathon $22 \mathrm{KBR}$, Fisher Scientific, Pittsburgh, PA). Serum samples were stored frozen for later analyses of serum bone metabolism markers (Liesegang et al., 2000; Allen, 2003). Enzyme immunoassay for the quantitation of pyridinoline (PYD, Metra Serum PYD; Quidel, San Diego, CA) and OC (Metra Osteocalcin; Quidel, San Diego, CA) were performed at an optical density of $405 \mathrm{~nm}$ in a BioTek Powerwave XS microplate spectrophotometer using Gen5 Data 
Table 2. Ingredient and analyzed chemical contents of diets (mean $\pm \mathrm{SD}$ ) containing different $\mathrm{Ca}$ and $\mathrm{P}$ concentrations

\begin{tabular}{|c|c|c|c|c|c|}
\hline Item & \multicolumn{5}{|c|}{$\operatorname{Diet}^{1}$} \\
\hline \multicolumn{6}{|l|}{ Ingredients, \% of DM } \\
\hline Bermudagrass hay & 11.7 & $5.10 \pm 0.08$ & $5.16 \pm 0.09$ & $5.16 \pm 0.09$ & $5.17 \pm 0.09$ \\
\hline Corn silage & 45.6 & $37.3 \pm 2.2$ & $37.4 \pm 2.2$ & $37.4 \pm 2.2$ & $37.4 \pm 2.2$ \\
\hline Whole cottonseed & 3.91 & 0.0 & 0.0 & 0.0 & 0.0 \\
\hline SE Sta. Exp. Mineral ${ }^{3}$ & 0.43 & $0.51 \pm 0.01$ & $0.51 \pm 0.01$ & $0.51 \pm 0.02$ & $0.51 \pm 0.01$ \\
\hline Calcium carbonate & 0.00 & $0.69 \pm 0.06$ & $0.70 \pm 0.06$ & $0.70 \pm 0.06$ & $0.70 \pm 0.07$ \\
\hline Monosodium phosphate & 0.00 & $0.03 \pm 0.03$ & $0.03 \pm 0.03$ & $0.03 \pm 0.03$ & $0.03 \pm 0.03$ \\
\hline Salt & 0.00 & $0.66 \pm 0.15$ & $0.67 \pm 0.15$ & $0.67 \pm 0.15$ & $0.67 \pm 0.15$ \\
\hline \multicolumn{6}{|l|}{ Nutrient content ${ }^{4}$} \\
\hline DM, $\%$ as fed & $48.8 \pm 4.7$ & $50.6 \pm 3.4$ & $50.6 \pm 3.5$ & $51.0 \pm 3.7$ & $51.2 \pm 3.6$ \\
\hline $\mathrm{Mg}, \%$ of DM & $0.27 \pm 0.05$ & $0.31 \pm 0.05$ & $0.31 \pm 0.05$ & $0.31 \pm 0.05$ & $0.31 \pm 0.05$ \\
\hline $\mathrm{K}, \%$ of $\mathrm{DM}$ & $1.49 \pm 0.53$ & $1.36 \pm 0.50$ & $1.37 \pm 0.50$ & $1.37 \pm 0.50$ & $1.37 \pm 0.51$ \\
\hline RUP, $\%$ of DM & 4.60 & 6.50 & 6.50 & 6.60 & 6.50 \\
\hline $\mathrm{NE}_{\mathrm{L}}, \mathrm{Mcal} / \mathrm{kg}$ of DM & 1.62 & 1.59 & 1.60 & 1.58 & 1.59 \\
\hline NFC, $\%$ of $\mathrm{DM}$ & 36.9 & 42.6 & 42.9 & 42.9 & 43.3 \\
\hline $\mathrm{DCAD}, \mathrm{mEq} / \mathrm{kg}$ & 182.7 & 229.0 & 197.0 & 229.0 & 196.0 \\
\hline
\end{tabular}

${ }^{1} \mathrm{HCa}$ and $\mathrm{HP}$ indicate dietary concentration of Ca and P above NRC (2001) predicted requirement; LCa and LP indicate dietary concentration of Ca and P below NRC (2001) predicted requirement.

${ }^{2}$ Treatment mixes contained ground corn, calcium carbonate, and monosodium phosphate.

${ }^{3}$ Southeast Experiment Mineral Concentrate contained Na, 18.2\%; Cl, 27.3\%; Mg, 13.9\%; S, 5\%; K, 3.47\%; Ca, <1.5\%; Zn, 12,700 mg/kg; Mn, $4,139 \mathrm{mg} / \mathrm{kg} ; \mathrm{Cu}, 1,937 \mathrm{mg} / \mathrm{kg} ; \mathrm{I}, 182 \mathrm{mg} / \mathrm{kg} ; \mathrm{Co}, 96 \mathrm{mg} / \mathrm{kg} ; \mathrm{Se}, 55 \mathrm{mg} / \mathrm{kg}$; vitamin A, 1,146 kIU/kg; vitamin D, $231 \mathrm{kIU} / \mathrm{kg}$; and vitamin E, $3.81 \mathrm{kIU} / \mathrm{kg}$; manufactured for Kentwood Co-op (Kentwood, LA).

${ }^{4} \mathrm{RUP}, \mathrm{NE}_{\mathrm{L}}, \mathrm{NFC}$, and DCAD as estimated by NRC (2001).

Analysis Software (BioTek Instruments, Winooski, VT). Intra- and interassay coefficients of variation were, respectively, 9.35 and $18.4 \%$ for PYD and 10.2 and $16.3 \%$ for OC.

Feces were collected during 3 consecutive days when cows in a block averaged $20 \pm 4$ DIM. Blocks of 4 cows were corralled within the single-alley free stall to allow access between their respective automatic gates and 5 stalls. Cows were followed by an individual with 4 dedicated buckets attached to $150-\mathrm{cm}$ wooden poles to collect feces as they were voided. Two individuals accompanied the cows during milking. Feces were stored in 70-L plastic tubs. Weights were recorded and feces were blended using a mud-mixer attached to an electric drill before representative samples were taken 4 times a day at $6,12,18$, and $24 \mathrm{~h}$ after the morning TMR was fed. Apparent digestibility was calculated based on the average DMI measured during the $7 \mathrm{~d}$ ending with the fecal collection. Ten blocks (38 cows) out of the 13 blocks of cows were used for total fecal collection in the digestion trial because of labor and time constrains. Nutrient digestibility was calculated using the following equation (Church, 1988): $\frac{(\text { DM consumed }) \times(\% \text { nutrient in feed DM })-(\text { fecal DM }) \times(\% \text { nutrient in feces DM })}{(\text { DM consumed }) \times(\% \text { nutrient in feed DM })} \times 100$.

Apparent nutrient absorption was the difference between nutrient ingested and nutrient fecal excretion. Total absorbable requirement (TAR) was calculated for every cow used in the digestion study using the NRC (2001) model adjusted for BW and milk yield.

Body condition score $(1=$ thin to $5=$ fat $)$ was determined at $10 \mathrm{~d}$ before expected calving and at 30 DIM by 3 different evaluators (Wildman et al., 1982). Cows were weighed for 2 consecutive days after the a.m. milking, $10 \mathrm{~d}$ before expected calving, after calving, and 29 DIM. Weights and scores were averaged for the consecutive days and among scorers before statistical analyses.

\section{Statistical Analyses}

All the response variables were analyzed using the MIXED procedure of SAS (Littell et al., 1996; SAS Institute, 2003). Milk yield and DMI were analyzed 
including fixed effect of Ca, P, day (from 6 to 31 DIM), and their 2- and 3-way interactions in the model. Block was included in the model as random effect. Daily values were analyzed as repeated measures using a Toeplitz covariance structure. Block $\times \mathrm{Ca} \times \mathrm{P}$ was the subject of the repeated statement. The covariance structure was selected by choosing the best fitting model according to the Akaike information criterion. Average intake during the third week before calving was used as covariate for postpartum DMI. Milk production in the previous lactation was used as covariate for milk yield.

Body weight loss and BCS loss were analyzed including in the model $\mathrm{Ca}, \mathrm{P}$, and their interaction as fixed effects. Block was included in the model as a random term. The PYD and OC concentrations were analyzed including fixed effect of Ca, P, day (15 and 30 DIM), and their 2- and 3-way interactions in the model. Block and block $\times \mathrm{Ca} \times \mathrm{P}$ were included as random effects in the model. The OC and PYD measured at calving day were included in the model as a covariate. The statistical analysis of OC was conducted on the natural logarithm-transformed variable. Milk composition, digestibility data, and production traits measured during the digestibility portion of the trial were analyzed including $\mathrm{Ca}, \mathrm{P}$, and their interaction as fixed effects in the model. Block, block $\times \mathrm{Ca} \times \mathrm{P}$, and day (3 sampling days) were included in the model as random terms.

The Kenward-Roger denominator degrees of freedom adjustment was used in all the analyses. Values reported are least squares means. Significance was declared at $P$ $\leq 0.05$ and a trend was reported if $0.05<P \leq 0.10$.

\section{RESULTS AND DISCUSSION}

\section{Diets}

Ingredient composition, nutrient contents, and their respective variation (standard deviations) for diets fed during the dry period (standardization diet) and postcalving (treatment diets) are presented in Table 2. Dietary P content in the basal diet was higher and Ca content was lower than originally planned, particularly because of nutrient content in corn silage $(0.15 \% \mathrm{Ca}$ and $0.26 \% \mathrm{P}, \mathrm{DM}$ basis, Table 1). High Ca and $\mathrm{P}$ diets were 7 and $21 \%$ above NRC (2001) estimated requirements, and low $\mathrm{Ca}$ and $\mathrm{P}$ diets were 25 and $9 \%$ below NRC (2001) estimated requirements, respectively (Table 2). Calcium-to-phosphorus ratios in treatment rations ranged between $1: 1$ and 1.7:1, in accordance with the recommended range (NRC, 2001).

Typical feeds used to prepare the basal diet (LCaLP) in this study supplied almost all $\mathrm{P}$ requirements for early-lactation dairy cows, except for 3 blocks in which a small proportion of monosodium phosphate $(0.03 \%$,
DM basis) was used. More severe P deficiency could not be achieved without risking the use of feeds that could potentially limit animal performance because of dietary protein or energy deficiencies.

\section{Production Performance}

Pregnant cows averaged $13.9 \mathrm{~kg}$ of DMI during the last $3 \mathrm{wk}$ of gestation and reached lowest levels $(7.6 \mathrm{~kg} /$ cow) during the day immediately before calving and on the calving date. Multiparous cows used in this study achieved high levels of milk production during their first month of lactation, averaging more than $44 \mathrm{~kg} /$ cow per day. There was no significant $(P \geq 0.05)$ effect of $\mathrm{Ca}$ and $\mathrm{P}$ levels on feed consumption, milk yield, and yield of milk components (Table 3). Milk protein content decreased from 2.90 to $2.76 \%$ with higher dietary $\mathrm{Ca}$, but milk protein yield changed less than $2 \%$ $(30 \mathrm{~g})$ with dietary Ca. There was a tendency of lower fat yield for LCa diets compared with $\mathrm{HCa}$ diets $(P \leq$ $0.07)$. Somatic cell score tended $(P \leq 0.10)$ to increase with the extreme diets - both HCaHP and LCaLP (Ca $\times \mathrm{P}$ interaction) - but the physiologic significance of this finding is unclear. Cows in all treatments lost 2 to $2.5 \mathrm{~kg}$ of BW daily from calving to 30 DIM. Body condition score averaged 0.60 units lost between d 10 before expected calving to 30 DIM. Cows are expected to lose as much as 0.5 to 1.0 unit of BCS within the first $60 \mathrm{~d}$ of lactation (NRC, 2001). Given the body of research published in the last few decades, significant changes in production performance were not expected from early-lactation, high-producing cows fed diets containing $0.46 \% \mathrm{Ca}$ and $0.38 \% \mathrm{P}$ because bone mobilization is expected to supply sufficient mineral to correct for the dietary deficiency (Valk and Šebek, 1999; Wu et al., 2001; Taylor et al., 2009).

\section{Ca and P Apparent Digestibility}

Intake and milk yield during fecal collection were similar to the means obtained for the entire experimental period for all treatments $(21.3$ vs. $21.4 \mathrm{~kg} / \mathrm{d}$, and 44.4 vs. $43.9 \mathrm{~kg} / \mathrm{d}$, respectively). Dry matter digestibility was not significantly affected by mineral content in the diets (Table 4).

Calcium intake was $32 \mathrm{~g}$ greater with $\mathrm{HCa}$ than with LCa diets but fecal excretion was only $22 \mathrm{~g}$ higher for $\mathrm{HCa}$, suggesting that $\mathrm{LCa}$ diets and $\mathrm{HCa}$ diets absorbed Ca similarly. Fecal Ca excretion was higher with HCaHP, decreased with HCaLP, but tended to remain similar between $\mathrm{LCa}$ diets $(\mathrm{Ca} \times \mathrm{P}$ interaction; $P \leq 0.10)$. Calcium $\times$ phosphorus interaction was significant for $\mathrm{Ca}$ apparent digestibility and $\mathrm{Ca}$ apparent absorption (ingested Ca minus fecal Ca). Dietary Ca 
Table 3. Performance of early lactation cows fed diets containing Ca and P above or below NRC (2001) estimated requirements in a factorial arrangement

\begin{tabular}{|c|c|c|c|c|c|c|c|c|}
\hline \multirow[b]{2}{*}{ Item } & \multicolumn{4}{|c|}{ Treatment $^{1}$} & \multirow[b]{2}{*}{ SEM } & \multicolumn{3}{|c|}{$\operatorname{Effect}^{2}(P>F)$} \\
\hline & $\mathrm{HCaHP}$ & HCaLP & LCaHP & LCaLP & & $\mathrm{Ca}$ & $\mathrm{P}$ & $\mathrm{Ca} \times \mathrm{P}$ \\
\hline $\mathrm{DMI}^{3} \mathrm{~kg} / \mathrm{d}$ & 21.0 & 20.7 & 21.9 & 21.4 & 0.57 & 0.26 & 0.53 & 0.90 \\
\hline Milk fat, \% & 3.57 & 3.64 & 3.63 & 3.27 & 0.22 & 0.41 & 0.44 & 0.25 \\
\hline Fat yield, $\mathrm{kg} / \mathrm{d}$ & 1.74 & 1.80 & 1.69 & 1.53 & 0.10 & 0.07 & 0.56 & 0.21 \\
\hline Milk protein, \% & 2.70 & 2.81 & 2.92 & 2.88 & 0.08 & 0.02 & 0.51 & 0.20 \\
\hline BW lost,${ }_{5}^{4} \mathrm{~kg} / \mathrm{d}$ & 2.16 & 2.51 & 2.11 & 2.13 & 0.66 & 0.42 & 0.50 & 0.53 \\
\hline BCS lost ${ }^{5}$ & 0.66 & 0.56 & 0.62 & 0.56 & 0.08 & 0.85 & 0.25 & 0.38 \\
\hline
\end{tabular}

${ }^{1}$ Treatment mineral contents in the diet DM: $\mathrm{HCaHP}=0.63 \% \mathrm{Ca}$ and $0.47 \% \mathrm{P} ; \mathrm{HCaLP}=0.65 \% \mathrm{Ca}$ and $0.37 \% \mathrm{P} ; \mathrm{LCaHP}=0.46 \% \mathrm{Ca}$ and $0.47 \% \mathrm{P}$; and $\mathrm{LCaLP}=0.45 \% \mathrm{Ca}$ and $0.38 \% \mathrm{P}$.

${ }^{2} \mathrm{Ca}=$ main effect of dietary calcium; $\mathrm{P}=$ main effect of dietary phosphorus; $\mathrm{Ca} \times \mathrm{P}=$ interaction between dietary $\mathrm{Ca}$ and $\mathrm{P}$.

${ }^{3}$ From DIM 6 to 31

${ }^{4}$ From calving to 30 DIM.

${ }^{5}$ From BCS measured at $10 \mathrm{~d}$ before expected calving date to BCS measured at $30 \mathrm{~d}$ after calving.

digestibility averaged $21.4 \%$ with HCaHP and LCaLP, whereas treatments $\mathrm{HCaLP}$ and LCaHP resulted in higher Ca digestibility (32.8\%). Low digestibility was expected with mature cows in all treatments, particularly those on HCaHP treatment (NRC, 2001). Somewhat unexpected was the low digestibility with LCaLP treatment. Braithwaite (1983a) estimated Ca digestibility in ewes at $13 \%$ for the "plentiful" $\mathrm{Ca}$ and $\mathrm{P}$ treatment diet between 14 and $21 \mathrm{~d}$ in milk. Calcium digestibility was $48 \%$ with ewes fed recommended $\mathrm{Ca}$ and $\mathrm{P}$ levels (Braithwaite, 1983a). Calcium digestibility in cows (primiparous and multiparous) fed $0.52 \%$ dietary $\mathrm{Ca}$ and $0.34 \%$ dietary $\mathrm{P}$ was $32.1 \%$ during the second week and $27.6 \%$ during the fifth week of lactation (Taylor et al., 2009). Calcium and $\mathrm{P}$ deficiencies are thought to independently influence $1,25-(\mathrm{OH})_{2} \mathrm{D}_{3}$ hydroxylation,

Table 4. Digestion trials of 39 early-lactation cows fed diets containing Ca and P above or below NRC (2001) estimated requirements in a factorial arrangement

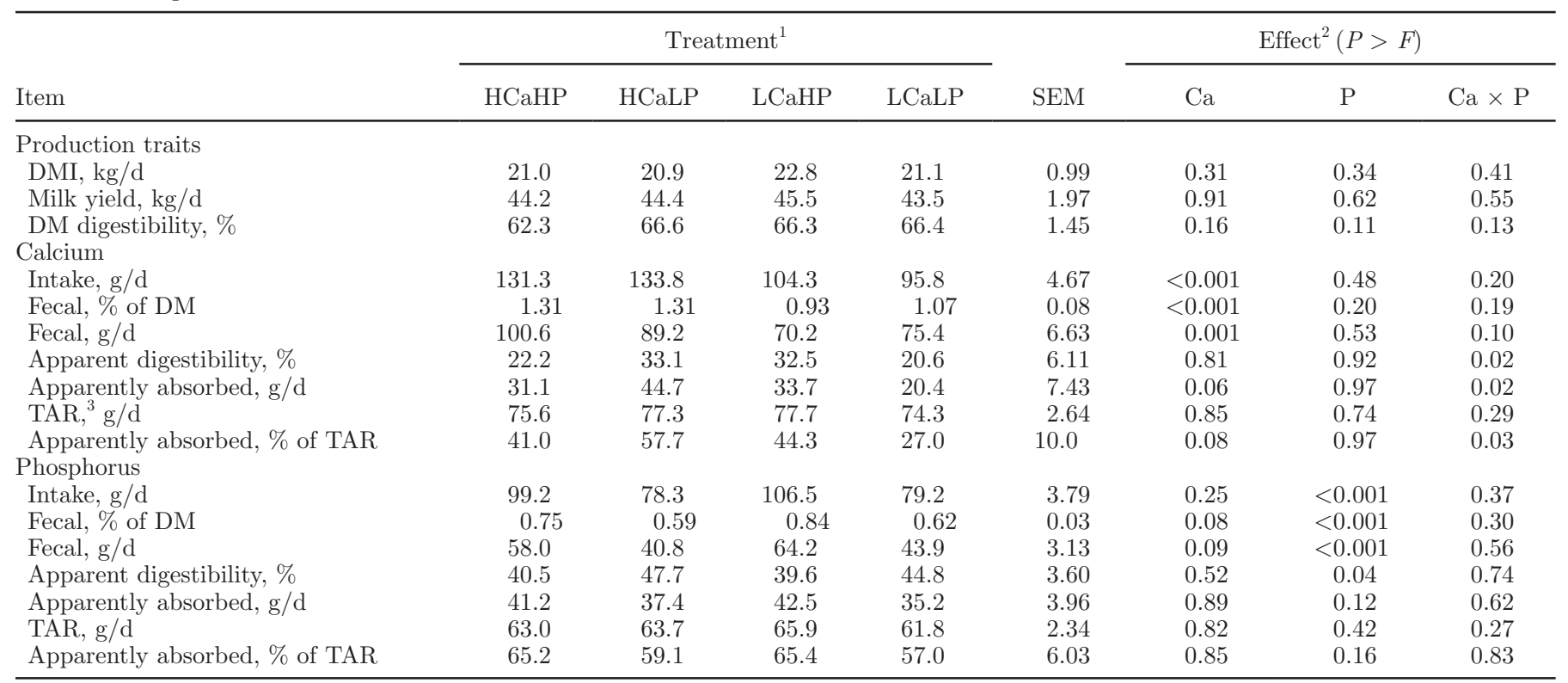

${ }^{1}$ Treatment mineral contents in the diet $\mathrm{DM}: \mathrm{HCaHP}=0.63 \% \mathrm{Ca}$ and $0.47 \% \mathrm{P} ; \mathrm{HCaLP}=0.65 \% \mathrm{Ca}$ and $0.37 \% \mathrm{P} ; \mathrm{LCaHP}=0.46 \% \mathrm{Ca}$ and $0.47 \% \mathrm{P}$; and LCaLP $=0.45 \% \mathrm{Ca}$ and $0.38 \% \mathrm{P}$.

${ }^{2} \mathrm{Ca}=$ main effect of dietary calcium; $\mathrm{P}=$ main effect of dietary phosphorus; $\mathrm{Ca} \times \mathrm{P}=$ interaction between dietary $\mathrm{Ca}$ and $\mathrm{P}$.

${ }^{3} \mathrm{TAR}=$ total absorbed requirements, calculated using the NRC (2001) model adjusted for BW and milk yield (assuming $1.22 \mathrm{~g}$ of Ca and 0.90 $\mathrm{g}$ of $\mathrm{P} / \mathrm{kg}$ of milk) of every cow used in digestion trials. 
but it has been suggested that HP suppresses kidney Q-hydroxylase function (Horst et al., 1994). Calcium digestibility and $\mathrm{Ca}$ apparent absorption in the current study appeared to be negatively influenced by $\mathrm{P}$ when dietary $\mathrm{Ca}$ was plentiful (HCa treatments). Phosphorus influence on Ca digestibility and apparent absorption was positive in LCa diets. Very low dietary Ca levels $(0.46 \% \mathrm{Ca})$ fed in this trial may have limited Ca excretion to inevitable losses and nonabsorbed dietary $\mathrm{Ca}$, which may be high in early lactation. In this case, low $\mathrm{Ca}$ digestibility and low $\mathrm{Ca}$ apparent absorption observed with cows fed LCaLP could have been the combination of $8.5 \mathrm{~g} / \mathrm{d}$ lower Ca intake, $5.8 \mathrm{~g} / \mathrm{d}$ higher fecal Ca output with LCaLP compared with LCaHP, and low $\mathrm{Ca}$ absorption efficiency in early-lactation cows across all treatments. High dietary $\mathrm{P}$ may have limited $\mathrm{Ca}$ absorption in $\mathrm{HCa}$ diets because $\mathrm{HCaLP}$ had similar $\mathrm{Ca}$ intake but significantly lower fecal $\mathrm{Ca}$ output than HCaHP. However, HP had little influence on fecal $\mathrm{Ca}$ excretion in $\mathrm{LCa}$ diets. In fact, cows in LCaHP appeared to absorb Ca even more efficiently than LCaLP. Absorption was probably at its maximum capacity in LCa diets. In that case, priority was given to $\mathrm{Ca}$ absorption, whereas with $\mathrm{HCa}$ diets some active absorption may occur. Active absorption may have been limited by diminished kidney $\alpha$-hydroxylase function in HCaHP because of $\mathrm{P}$ negative feedback.

Phosphorus intake, fecal output $(\mathrm{g} / \mathrm{d}$ and $\%$ of fecal $\mathrm{DM})$, and digestibility were significantly affected by $\mathrm{P}$ content in the diets. A tendency $(P \leq 0.09)$ for lower fecal P output (g/d and \% of fecal DM) with HCa diets $(4.67 \mathrm{~g} / \mathrm{d})$ was likely the result of cows ingesting $4.12 \mathrm{~g}$ more $\mathrm{P}$ in $\mathrm{LCa}$ diets than $\mathrm{HCa}$ diets, as a consequence of $\mathrm{P}$ intake in LCaHP diet (Table 4). Phosphorus apparent absorption was not affected by $\mathrm{Ca}$ or $\mathrm{P}$.

In the present study, treatment diets appeared to supply insufficient apparently absorbed Ca and P. Total absorbable requirements averaged about $76 \mathrm{~g}$ of absorbed Ca per day and $64 \mathrm{~g}$ of absorbed $\mathrm{P}$ per day (Table 4). Treatment diets supplied between 27 and $58 \%$ Ca TAR and between 57 and $65 \% \mathrm{P}$ TAR. Apparent digestibility represents the least possible absorption coefficient because of the contribution of endogenous sources of $\mathrm{Ca}$ and $\mathrm{P}$. True absorption is most likely higher than apparent absorption, suggesting that at most 33 to 54 $\mathrm{g}$ of $\mathrm{Ca}$ and 22 to $27 \mathrm{~g}$ of $\mathrm{P}$ needed to be supplied daily by endogenous sources as secreted minerals reabsorbed from the intestines or bone mineral resorption. Assuming that apparent absorption measured in this study was the average for the experimental period, we can estimate the upper limit for bone resorption to be between 990 and 1,620 g of $\mathrm{Ca}$ and from 660 to $810 \mathrm{~g}$ of $\mathrm{P}$ for the diets fed in the present study.
Phosphorus intake increased protein output in feces $(P \leq 0.04)$. Cows fed HP diets excreted $124 \mathrm{~g}$ more CP in feces than cows fed LP diets, regardless of dietary Ca. Higher CP fecal excretion was not a result of higher CP intake or lower milk protein yield. Phosphorus supplementation has been shown to increase the efficiency of microbial protein synthesis from nonprotein nitrogen (Komisarczuk-Bony and Durand, 1991). In the present study, fecal microbial protein was not measured, but it could represent as much as a $10 \%$ decrease in potentially labile $\mathrm{N}$ if the increase in fecal $\mathrm{N}$ output occurred because of microbial growth in the large intestine at the expense of urinary $\mathrm{N}$.

\section{Bone Metabolism Markers}

Serum markers can replace more invasive techniques to establish patterns of bone turnover. Osteocalcin is a metabolite of protein synthesis by osteoblasts, which can be used as a marker for bone formation. Pyridinoline is a biomarker of bone resorption that can also be found in collagen type I from skin but can be safely detected in serum (Allen, 2003). For the purposes of this study, we specifically selected mature cows to minimize the effect of increased growth and remodeling of bone and skin tissues, conditions more likely to be observed in growing animals such as primiparous and second-lactation cows (Allen, 2003). Dietary Ca and $\mathrm{P}$ concentrations were not expected to significantly affect collagen metabolism in the skin of multiparous cows ( $\geq 3$ lactations), thus serum PYD concentration changes were attributed to bone resorption.

Osteocalcin. Serum OC was not affected by dietary Ca or P levels (Table 5) but changed over time (Figure 1). Serum concentration of OC reached a nadir immediately after calving, returned to precalving levels $(\sim 30$ $\mathrm{ng} / \mathrm{mL}$ ) at $15 \mathrm{~d}$ postpartum, and continued to increase through the end of the study at 30 DIM. The decrease in plasma OC concentration could be a result of increased PTH in the bloodstream around parturition (Naito et al., 1990). The pattern of change in serum OC concentration was similar to that in other studies (Naito et al., 1990; Liesegang et al., 2000; Taylor et al., 2009). Liesegang et al. (2000) reported serum OC concentrations below $1 \mathrm{ng} / \mathrm{mL}$ throughout the lactation of Brown Swiss and crosses of Brown Swiss cows with significantly higher concentrations for cows producing more milk. Peterson et al. (2005) observed OC content in serum similar for multiparous Holstein cows fed different P contents in the prepartum. Serum OC means were similar to those found in our study during the dry period, but concentrations were lower ranging between 19.7 and $21.4 \mathrm{ng} / \mathrm{mL}$ in lactating cows from calving 
Table 5. Natural logarithm of serum osteocalcin (OC) concentration and pyridinoline (PYD) concentration of early-lactation cows fed diets containing $\mathrm{Ca}$ and $\mathrm{P}$ above or below NRC (2001) estimated requirements in a factorial arrangement ${ }^{1}$

\begin{tabular}{|c|c|c|c|c|c|c|c|c|}
\hline \multirow[b]{2}{*}{ Item } & \multicolumn{4}{|c|}{ Treatment $^{2}$} & \multirow[b]{2}{*}{ SEM } & \multicolumn{3}{|c|}{ Effect $^{3}$} \\
\hline & HCaHP & HCaLP & LCaHP & LCaLP & & $\mathrm{Ca}$ & $\mathrm{P}$ & $\mathrm{Ca} \times \mathrm{P}$ \\
\hline
\end{tabular}

${ }^{1}$ Concentrations represent means of samples collected at 15 and 30 DIM.

${ }^{2}$ Treatment mineral contents in the diet DM: HCaHP $=0.63 \% \mathrm{Ca}$ and $0.47 \% \mathrm{P} ; \mathrm{HCaLP}=0.65 \% \mathrm{Ca}$ and $0.37 \% \mathrm{P} ; \mathrm{LCaHP}=0.46 \% \mathrm{Ca}$ and $0.47 \% \mathrm{P}$; and $\mathrm{LCaLP}=0.45 \% \mathrm{Ca}$ and $0.38 \% \mathrm{P}$.

${ }^{3} \mathrm{Ca}=$ main effect of dietary calcium; $\mathrm{P}=$ main effect of dietary phosphorus; $\mathrm{Ca} \times \mathrm{P}=$ interaction between dietary $\mathrm{Ca}$ and $\mathrm{P}$.

to 28 DIM. Serum OC contents in the present study were within the range observed in a recent study in which multiparous Holstein cows were fed 0.52, 0.78, and $1.03 \% \mathrm{Ca}$ and $0.34 \% \mathrm{P}$ on a DM basis (Taylor et al., 2009).

Serum OC reached a peak around 60 DIM in 2 studies (Liesegang et al., 2000; Taylor et al., 2009). Peak serum OC was achieved between 20 and 30 wk of lactation in Swedish Red and White cows (Ekelund et al., 2006). Ekelund et al. (2006) observed a treatment by time interaction with higher serum OC concentration between 17 and 20 wk of lactation for cows fed the lower $\mathrm{P}$ content diet compared with adequate $\mathrm{P}$ content diet. The difference in serum OC concentrations was narrow during the dry period and early lactation among cows fed diets containing either $0.31 \%$ or $0.41 \% \mathrm{P}$ and $0.64 \%$ Ca, DM basis (Ekelund et al., 2006). Another study compared serum OC from cows fed different dietary $\mathrm{P}$ levels prepartum (Peterson et al., 2005). A significant treatment by time interaction was observed in serum OC measured on d $0,1,2,3$, and 14 postpartum, but the difference was considered small (Peterson et al.,

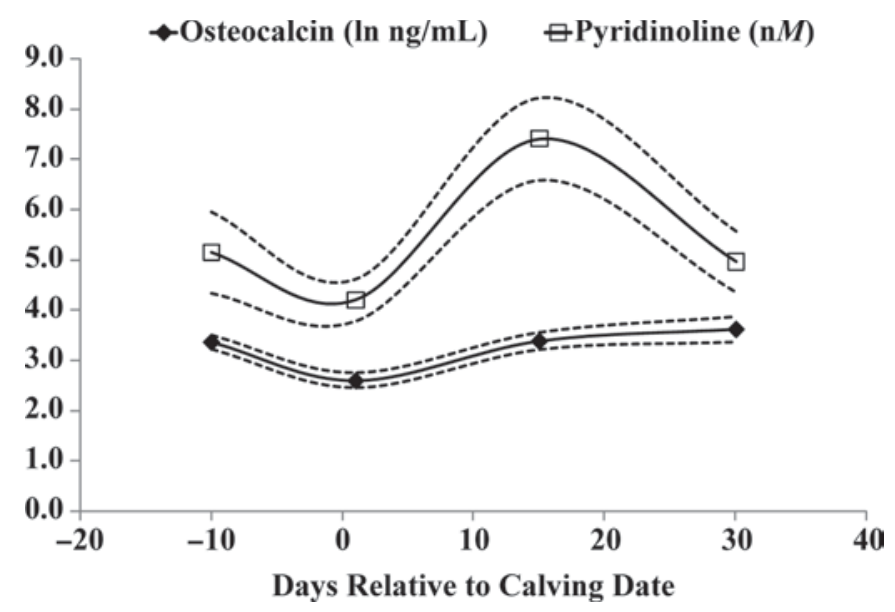

Figure 1. Natural logarithm of serum osteocalcin $(\bullet)$ and serum pyridinoline $(\square)$ content of mature cows from $10 \mathrm{~d}$ before expected calving date to 30 DIM. Dashed lines represent the $95 \%$ confidence interval.
2005). Concentrations of OC in serum indicated that osteoblastic activity was increasing for all treatments in the present study. Serum OC concentrations were numerically higher and the gap increased over time for cows fed $\mathrm{HCa}$ and LP diets compared with LCa and HP diets in our study, but those differences were not significant.

Despite seemingly contradictory results for serum OC concentrations among published studies, it is reasonable to expect that bone accretion rates, and thus serum OC, changes with $\mathrm{Ca}$ and $\mathrm{P}$ dietary contents. However, the demands for $\mathrm{Ca}$ and $\mathrm{P}$ by early-lactation cows can supplant their ability to absorb from intestines or mobilize from the bones. Peterson et al. (2005) suggested that a $\mathrm{P}$ deficiency could elicit a reduction in bone formation to aid in the maintenance of adequate phosphatemia and calcemia. Because it appears that all treatments resulted in considerable mobilization, significant differences in serum OC should be expected only after bone stores of $\mathrm{Ca}$ and $\mathrm{P}$ are depleted or demand for milk production over intestinal absorption supply decreases. Serum OC differences should be expected after milk yield peak and as DMI reaches its maximum, thus later in the lactation cycle. Our study may have been too short to detect significant differences in serum $\mathrm{OC}$ induced by dietary $\mathrm{Ca}$ or $\mathrm{P}$.

Pyridinoline. Serum PYD concentration in multiparous cows fed $\mathrm{HCa}$ was $1 \mathrm{n} M$ lower $(P \leq 0.01)$ than in cows fed LCa (Table 5). Cows in HCaHP treatment had the lowest serum PYD concentration among all treatments. The interaction between $\mathrm{Ca}$ and $\mathrm{P}$ tended to be significant $(P \leq 0.08)$, suggesting that $\mathrm{P}$ levels may affect bone mobilization differently with $\mathrm{HCa}$ versus LCa. Phosphorus levels had little effect between $\mathrm{HCa}$ diets. Pyridinoline concentration was highest in the serum of cows fed LCaHP. Furthermore, serum PYD concentration was similar at 15 DIM for cows fed HP or LP. Cows fed HP treatments tended to show a slower rate of decline of serum PYD $(P \leq 0.09)$ compared with LP diets from 15 to 30 DIM (24 vs. 40\%, respectively), but no interaction over time was observed for Ca levels 
in the diets (Figure 2). These observations suggest that HP could delay the return of bone mobilization to basal levels when LCa was fed to multiparous cows.

Serum PYD concentration was significantly affected by time (Figure 1). Lowest PYD concentration was observed on calving day and reached highest levels when cows were 15 DIM. Serum PYD of cows at 30 DIM returned to concentrations similar to those observed in cows $10 \mathrm{~d}$ before expected calving. Other studies also noted that lactating cows adequately fed $\mathrm{Ca}$ and $\mathrm{P}$ peaked in deoxypiridinoline (Liesegang et al., 2000; Taylor et al., 2009) and CTx (Liesegang et al., 2000; Ekelund et al., 2006) serum concentrations around 15 $\mathrm{d}$ postpartum. Serum deoxypyridinoline in mature cows also returned to precalving period levels after approximately 30 DIM (Taylor et al., 2009). Concentrations of PYD observed by Liesegang et al. (2000) were not comparable to those obtained in the current study because PYD was determined in urine samples in that study. The authors observed similar peak PYD concentration in the urine of cows around 14 DIM, but values reached prepartum levels only around 150 DIM. A reason for that discrepancy with serum PYD concentration pattern over time may have been because the dry cow diet was limited in $\mathrm{Ca}(0.34 \% \mathrm{DM})$ and $\mathrm{P}(0.33 \% \mathrm{DM})$ in the present study, whereas Liesegang et al. (2000) fed diets containing very high levels of $\mathrm{Ca}(0.58 \% \mathrm{DM})$ and $\mathrm{P}$ $(0.56 \% \mathrm{DM})$ in the prepartum period. Bone resorption was probably stimulated shortly after late-gestation cows were offered the standard nonlactating cow TMR in this study, thus releasing larger quantities of PYD in the bloodstream. An alternative explanation could be that Brown Swiss cows (used in Liesegang et al., 2000) respond differently to $\mathrm{Ca}$ demands with longer periods of bone mobilization throughout lactation compared with Holstein cows used in our study.

\section{Reconciling Digestibility and Bone Metabolism Markers Results}

Calcium and $\mathrm{P}$ metabolism are inextricably associated in lactating cows. High dietary Ca should increase the supply of Ca available for milk production, decreasing the need for bone mobilization in early-lactation dairy cows. Hypocalcemia and very low phosphatemia can independently stimulate kidneys to produce $1,25-(\mathrm{OH})_{2} \mathrm{D}_{3}$ or enhance intestinal receptor binding affinity to $1,25-(\mathrm{OH})_{2} \mathrm{D}_{3}$, thus changing intestinal absorption of both Ca and P (Horst, 1986; Breves and Schröder, 1991). In fact, Kichura et al. (1982) showed a tendency for greater $1,25-(\mathrm{OH})_{2} \mathrm{D}_{3}$ when pregnant, nonlactating Jersey cows were fed $86 \mathrm{~g}$ of $\mathrm{Ca}$ and $10 \mathrm{~g}$ of $\mathrm{P}$. On the other hand, it has been suggested that intestinal absorption of Ca can be limited when an excessive sup-

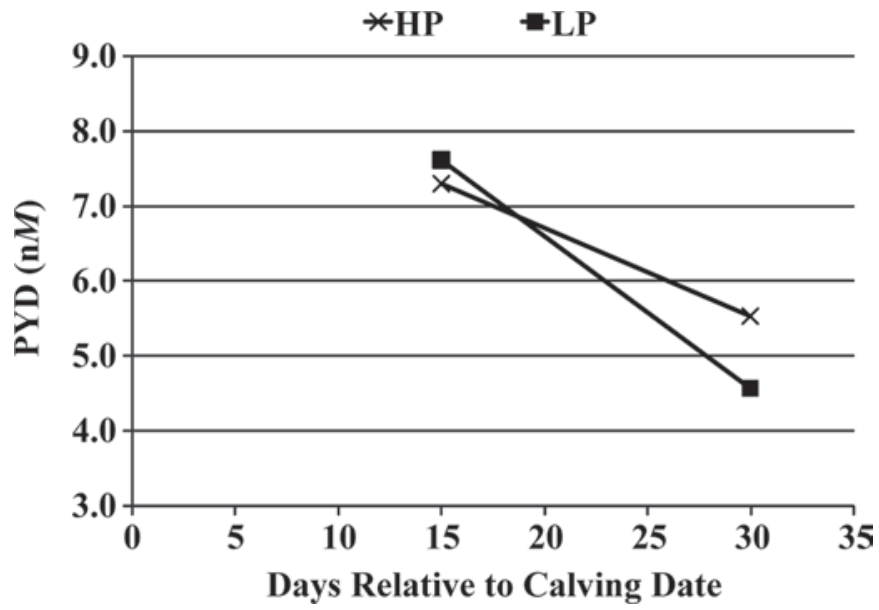

Figure 2. Dietary $\mathrm{P}$ by time interaction for serum pyridinoline (PYD) concentration in mature cows at 15 and 30 DIM $(P \leq 0.09)$. Treatments contained $0.47 \% \mathrm{P}(\mathrm{HP}: \times)$ and $0.38 \% \mathrm{P}(\mathrm{LP}: \mathbf{\square})$ in the diet DM.

ply of $\mathrm{P}$ suppresses $\alpha$-hydroxylase activity, the enzyme responsible for most $1,25-(\mathrm{OH})_{2} \mathrm{D}_{3}$ production in the kidneys, rendering active gastrointestinal absorption of P and Ca less efficient (Horst et al., 1994; NRC, 2001). In summary, dietary $\mathrm{P}$ may indirectly influence $\mathrm{Ca}$ absorption in the intestines by affecting $1,25-(\mathrm{OH})_{2} \mathrm{D}_{3}$ hydroxylation in the kidneys or by changing intestinal $1,25-(\mathrm{OH})_{2} \mathrm{D}_{3}$ receptor binding affinity (Kichura et al., 1982; Horst, 1986; Goff, 2006).

In our study, Ca apparent absorption was higher and serum PYD lower in cows fed HCa diets. Higher absorption was observed in cows ingesting $\mathrm{HCaLP}$ diet, but PYD was similar between dietary P levels in HCa diets. These results seem to be in agreement with the observations of Kichura et al. (1982), suggesting higher Ca absorption in low P diets. Serum PYD of cows fed HP diets suggested an extended period of bone resorption, which also appears to agree with lower $\mathrm{Ca}$ absorption with high $\mathrm{P}$ diets. However, cows fed low dietary Ca had higher $\mathrm{Ca}$ apparent absorption when $\mathrm{P}$ level was similar (LCaHP). Although Ca apparent absorption was similar between HCaHP and LCaHP (31 and $34 \mathrm{~g} / \mathrm{d}$ ), PYD treatment means were, respectively, 5.58 and 7.25 $\mathrm{n} M$, the lowest and highest among the 4 treatments. These results seem to suggest that cows in deficiency of Ca can override a negative $\mathrm{P}$ feedback; however, Ca absorption in LCaHP was ineffective in reducing bone resorption. It appears that dietary $\mathrm{Ca}$ and $\mathrm{P}$ levels can both independently influence bone resorption in early lactation dairy cows.

\section{CONCLUSIONS}

Dietary $\mathrm{Ca}$ and $\mathrm{P}$ contents had no significant effect on feed intake, milk yield, or milk components yield 
during the first month of lactation. Calcium intake negatively affected concentrations of the bone resorption biomarker pyridinoline. Cows fed $100 \mathrm{~g}$ of $\mathrm{P} / \mathrm{d}$ had higher bone resorption $(\mathrm{Ca} \times \mathrm{P}$ interaction) shown as an extended period of high serum pyridinoline levels ( $\mathrm{P}$ $\times$ time interaction). Calcium content in the diets did not influence $\mathrm{P}$ digestion. Results of this study suggest that $\mathrm{P}$ not only could but should be reduced in early-lactation, high-producing cows to allow for more efficient dietary Ca utilization.

\section{ACKNOWLEDGMENTS}

The authors thank the Louisiana State University AgCenter Southeast Research Station's dairy crew for feeding, milking, and caring of the cows. Assistance provided by Bill Barber, Regina Barnett, Catherine Cox, Tara Doughty, Justin Jones, Douglas McKean, Jerry Simmons, and Randy Walz during feed and fecal collections and analyses is sincerely appreciated. The authors are also grateful to Ashley Howard and Jennifer Laborde at LSU AgCenter School of Animal Sciences for their skillful technical assistance with the analyses of serum osteocalcin and pyridinoline.

\section{REFERENCES}

Allen, M. J. 2003. Biochemical markers of bone metabolism in animals Uses and limitations. Vet. Clin. Pathol. 32:101-113.

Braithwaite, G. D. 1983a. Calcium and phosphorus requirements of the ewe during pregnancy and lactation. 1. Calcium. Br. J. Nutr. 50:711-722.

Braithwaite, G. D. 1983b. Calcium and phosphorus requirements of the ewe during pregnancy and lactation. 2. Phosphorus. Br. J. Nutr. 50:723-736.

Breves, G., and B. Schröder. 1991. Comparative aspects of gastrointestinal phosphorus metabolism. Nutr. Res. Rev. 4:125140.

Church, D. C. 1988. The Ruminant Animal - Digestive Physiology and Nutrition. Prentice-Hall, Prospect Heights, IL.

Ekelund, A., R. Spörndly, and K. Holtenius. 2006. Influence of low phosphorus intake during early lactation on apparent digestibility of phosphorus and bone metabolism in dairy cows. Livest. Sci. 99:227-236.

Goff, J. P. 2000. Pathophysiology of calcium and phosphorus disorders. Vet. Clin. North Am. Food Anim. Pract. 16:319-337.

Goff, J. P. 2006. Macromineral physiology and application to the feeding of the dairy cow for prevention of milk fever and other periparturient mineral disorders. Anim. Feed Sci. Technol. 126:237-257.

Horst, R. L. 1986. Regulation of calcium and phosphorus homeostasis in the dairy cow. J. Dairy Sci. 69:604-616.

Horst, R. L., J. P. Goff, and T. A. Reinhardt. 1994. Calcium and vitamin D metabolism in the dairy cow. J. Dairy Sci. 77:19361951.

Kichura, T. S., R. L. Horst, D. C. Beitz, and E. T. Littledike. 1982 Relationships between prepartal dietary calcium and phosphorus, vitamin $\mathrm{D}$ metabolism, and parturient paresis in dairy cows. J. Nutr. 112:480-487.

Kincaid, R. L., J. K. Hillers, and J. D. Cronrath. 1981. Calcium and phosphorus supplementation of rations for lactating cows. J. Dairy Sci. 64:754-758
Knowlton, K. F., and J. H. Herbein. 2002. Phosphorus partition during early lactation in dairy cows fed diets varying in phosphorus content. J. Dairy Sci. 85:1227-1236.

Komisarczuk-Bony, S., and M. Durand. 1991. Effects of minerals on microbial metabolism. Pages $179-198$ in Rumen Microbial Metabolism and Ruminant Digestion. J. P. Jouany, ed. INRA, Paris, France.

Liesegang, A., R. Elcher, M.-L. Sassi, J. Risteli, M. Kraenzlin, J.L. Riond, and M. Wanner. 2000. Biochemical markers of bone formation and resorption around parturition and during lactation in dairy cows with high and low standard milk yields. J. Dairy Sci. 83:1773-1781

Littell, R. C., G. A. Milliken, W. W. Stroup, R. D. Wolfinger, and O. Schabenger. 1996. SAS for Mixed Models. 2nd ed. SAS Inst. Inc, Cary, NC.

Lopez, H., F. D. Kanitz, V. R. Moreira, L. D. Satter, and M. C. Wiltbank. 2004a. Reproductive performance of dairy cows fed two concentrations of phosphorus. J. Dairy Sci. 87:146-157.

Lopez, H., F. D. Kanitz, V. R. Moreira, M. C. Wiltbank, and L. D. Satter. 2004b. Effect of dietary phosphorus on performance of lactating dairy cows: Milk production and cow health. J. Dairy Sci. $87: 139-146$.

Martz, F. A., A. T. Belo, M. F. Weiss, R. L. Belyea, and J. P. Goff. 1990. True absorption of calcium and phosphorus from alfalfa and corn silage when fed to lactating cows. J. Dairy Sci. 73:12881295

Naito, Y., N. Shindo, R. Sato, and D. Murakami. 1990. Plasma osteocalcin in preparturient and postparturient cows: Correlation with plasma 1,25-dihydroxyvitamin $\mathrm{D}$, calcium, and inorganic phosphorus. J. Dairy Sci. 73:3481-3484.

NRC. 2001. Nutrient Requirements of Dairy Cattle. Natl. Acad. Sci., Washington, DC.

Peterson, A. B., M. W. Orth, J. P. Goff, and D. K. Beede. 2005 Periparturient responses of multiparous Holstein cows fed different dietary phosphorus concentrations prepartum. J. Dairy Sci. 88:3582-3594.

SAS Institute. 2003. SAS/STAT User's Guide (Version 9.1.3 Service Pack 4). Cary, NC.

Spiekers, H., R. Brintrup, M. Balmelli, and E. Pfeffer. 1993. Influence of dry matter intake on faecal phosphorus losses in dairy cows fed rations low in phosphorus. J. Anim. Physiol. Anim. Nutr. (Berl.) 69:37-43.

Taylor, M. S., K. F. Knowlton, M. L. McGilliard, W. S. Swecker, J. D. Ferguson, and Z. Wu. 2009. Dietary calcium has little effect on mineral balance and bone mineral metabolism through twenty weeks of lactation in Holstein cows. J. Dairy Sci. 92:223-237.

Ternouth, J. H. 1990. Phosphorus and beef production in northern Australia. 3. Phosphorus in cattle-A review. Trop. Grassl. $24: 159-169$

Valk, H., and L. B. J. Šebek. 1999. Influence of long-term feeding of limited amounts of phosphorus on dry matter intake, milk production, and body weight of dairy cows. J. Dairy Sci. 82:21572163.

Van Soest, P. J., J. B. Robertson, and B. A. Lewis. 1991. Methods for dietary fiber, neutral detergent fiber, and nonstarch polysaccharides in relation to animal nutrition. J. Dairy Sci. 74:3583-3597.

Wildman, E. E., G. M. Jones, P. E. Wagner, R. L. Boman, J. H. F. Troutt, and T. N. Lesch. 1982. A dairy cow body condition scoring system and its relationship to standard production characteristics. J. Dairy Sci. 65:495-501.

Wu, Z. L. D. Satter, A. J. Blohowiak, R. H. Stauffacher, and J. H. Wilson. 2001. Milk production, estimated phosphorus excretion, and bone characteristics of dairy cows fed different amounts of phosphorus for two or three years. J. Dairy Sci. 84:1738-1748.

Wu, Z., L. D. Satter, and R. Sojo. 2000. Milk production, reproductive performance, and fecal excretion of phosphorus by dairy cows fed three amounts of phosphorus. J. Dairy Sci. 83:1028-1041. 